\title{
Relationships among Job Satisfaction, Organizational Commitment, and Turnover Intention: Evidence from the Gambling Industry in Macau
}

\author{
Jen Hung Wang ${ }^{1}$, Kuan Chen Tsai ${ }^{2}$, Luo Jia Ru Lei ${ }^{1}$, Im Fan Chio ${ }^{1}$, Sut Kam Lai ${ }^{1}$ \\ ${ }^{1}$ Faculty of Business, City University of Macau, Macau, China \\ ${ }^{2}$ Faculty of Humanities and Social Sciences, City University of Macau, Macau, China \\ Correspondence: Kuan Chen Tsai, Faculty of Humanities and Social Sciences, City University of Macau, Avenida Padre \\ Tomás Pereira Taipa, Macau, China
}

Received: January 4, 2016 Accepted: February 14, 2016 Online Published: February 22, 2016

doi:10.11114/bms.v2i1.1280

URL: http://dx.doi.org/10.11114/bms.v2i1.1280

\begin{abstract}
The purpose of this study was to examine the relationships among job satisfaction, organizational commitment, and turnover intention of workers in two casinos in Macau. The current study was a correlational study and used convenience sampling, and a total of 105 surveys were retrieved from employees working in two casinos in Macau. For our sample, we found that job satisfaction had a significant and positive correlation with organizational commitment. We also found that the association between job satisfaction and turnover intention was positive but not significant and the association between organizational commitment and turnover intention was negative but not significant. Finally, the regression model indicated that job satisfaction and organizational commitment were effective predictors of employees' turnover intention.
\end{abstract}

Keywords: job satisfaction, organizational commitment, turnover intention

\section{Introduction}

Employees are the type of capital most important capital to organizational survival (Short \& Harris, 2010). Huang and Hsiao (2007) found that the better the working conditions, the higher the levels of employees' organizational commitment - i.e., how strongly they want to be a part of the organization - and their job satisfaction. If people stay in one organization long enough to gain experience that benefits them in their efforts to obtain promotion and/or work of a more interesting nature, they will be more satisfied with their jobs and have stronger commitment to them (Meyer \& Allen, 1991). As such, how to improve employees' job satisfaction and organizational commitment and decrease employee turnover rates are vital issues for organizational development.

The gambling industry is the backbone of Macau's economy, and involves an estimated $25 \%$ of the working population (Chi \& Zheng, 2009). Demand for high-quality human resources is increasing in this industry. Consequently, the purpose of the current study was to examine the relationships among job satisfaction, organizational commitment, and turnover intention of workers in two casinos in Macau. In addition, the unique of this study was to help Macau government and gambling industry regulate necessary policies in order to cultivate employees' job environment being more friendly.

\section{Literature Review}

\subsection{Job Satisfaction}

Job satisfaction is neither completely contingent upon personality characteristics nor upon external working conditions; rather, it is an attitude and feeling formed by the interplay between individual personal factors and the environment (Hoppock, 1935; Vroom, 1964). For Locke (1969), job satisfaction depended on the discrepancy an individual perceived between her real possession and her expectations: if this discrepancy is small or nonexistent, then the individual will feel satisfaction, and if it is large, she will feel dissatisfaction. Following this line of argument, Wanous and Lawler (1972) declared that real possession has more, and longer-term, influence than expectations do. That is, the level of job satisfaction is determined by how employees define the discrepancy, and everyone will therefore have different perceptions of job satisfaction with regard to the same job. 
Scholars have varying perspectives on the relationship between job satisfaction and organizational commitment. Porter et al. (1974) pointed out that job satisfaction is an important component of organizational commitment, with the former being closely related to working environment and therefore more changeable than organizational commitment is. Because job satisfaction is characterized by instability and variability, it can be viewed as a causal factor vis-à-vis organizational commitment, with Currivan (2000) suggested that the higher people job satisfaction, the higher their organizational commitment. Williams and Hazer (1986) argue that organizational commitment is contingent upon the individual's assessment of perceived interest and suggested that job satisfaction is an antecedent of organizational commitment. Other empirical studies also show similar results (e.g., Kah Loong, 2011; Lambert, Hogan, \& Keena, 2015).

\subsection{Organizational Commitment}

Organizational commitment is a multi-factor construct (Cohen, 2003) for which scholars have proposed several competing typologies. For example, Staw (1978) classifies it into attitude commitment and behavior commitment. The former refers to people recognizing the goals and values of the organization and being willing to work hard to fulfill its mission; individuals anticipate the cost of leaving the organization because (e.g., status, pension, friendships with colleagues), and making psychological adjustments to maintain the consistency of their manners. For Meyer and Allen (1991), there are three kinds of organizational commitment: (a) emotional commitment, which refers to a person's attachment to a specific organization; (b) continuous commitment, a person staying in an organization because of his beliefs; and (c) normative commitment, a person staying within an organization out of a sense of responsibility or obligation.

Organizational commitment generally refers to the level of employees' loyalty, involvement, and recognition. For employees, the higher the organizational commitment, the closer the tie to the organizational vision and beliefs, and in turn the lower the tendency toward turnover (Sušanj \& Jakopec, 2012). Turnover refers to a broken relationship between employer and employee, regardless of which party causes it to happens (Ferguson \& Ferguson, 1986). Several studies have found a negative relationship between organizational commitment and turnover intention (Sarah \& Daniel, 2000; Sousa-Poza \& Henneberger, 2004; Timothy, 2000). Mobley, Horner, and Hollingsworth (1978) reported that organizational commitment has a more important effect on turnover intention than job satisfaction does. The greater a person's age and experience level, the higher the level of organizational commitment that they tend to have. When people stay in an organization for a lengthy period of time, they will invest more time and energy in it, so for those who are senior in the organization will be reluctant to leave their jobs and display higher levels of organizational commitment (Salancik, 1977).

\subsection{Turnover}

Turnover can be grouped into two types: voluntary turnover and involuntary turnover. The results from employees factors such as retirement, health issues, the continuation of education, and promotion, while the latter is caused by employers, and includes discharges and layoffs (Wanous, 1979). Turnover intention is the last stage of a series of withdrawal cognition processes undergone by dissatisfied employees, and has been viewed as an antecedent variable that predicts real leaving behavior (Iverson \& Deery, 1997; Lance, 1991).

The turnover process, as long as an interactive relationship between employees and employers is not expected, or the employee has a negative impression of the job they do, will cause the termination of this relationship, which in turn affects the organization, society, and economy to some extent. Consequently, it is expected that a high turnover of employees represents an obstacle to the quality of service provided by an organization and leads to negative effects on organizational performance.

A number of studies have revealed a negative connection between job satisfaction and turnover intention (Biswas, 2009; Karatepe et al., 2007; Yang, 2008). People with lower levels of job satisfaction are often uninterested in their jobs, and do not receive recognition from others.

\section{Method}

\subsection{Participants}

We used convenience sampling, and a total of 111 questionnaires were initially distributed to employees working in two casinos in Macau. In all, 105 valid copies were retrieved, 42 of them completed by males and 63 by females. A large majority of the respondents (69.5\%) were aged 35 or younger, with $39 \%$ aged 26 to 35. Most participants (72.4\%) had not been educated beyond high school, and $48.6 \%$ had 1-5 years of experience in this industry.

\subsection{Instrument and Procedure}

The survey used in the current study consisted of four parts: background information, job satisfaction, organizational 
commitment, and turnover intention. All survey items were answered via a six-point Likert scale, ranging from 1, "completely disagree" to 6, "completely agree." Background information included age, gender, education, and years of experience.

The section dealing with job satisfaction included 17 questions, of which eight were drawn from Chang (2010), four from Chiang (2005), and five from Zhang (2004). One sample item from this section was, "I have opportunities to work independently." Cronbach's $\alpha$ for the job-satisfaction items was .870 .

The section covering organizational commitment included 13 statements, of which six were adopted from Chung (2005), four from Lo (2009), and three from Hou (2008). One sample item from this part was, "I can fully develop my abilities while working in this organization." Cronbach's $\alpha$ for the organizational-commitment items was .907.

The part of the survey dealing with turnover intention comprised eight questions, all adopted from Huang (2007); for example, "If I leave, I will easily find a suitable position in another organization." Cronbach's $\alpha$ for the turnover-intention items was .844 , and for all 38 non-background items was .901 , indicating that the instrument has a good overall reliability.

\subsection{Data Analysis}

The current study was correlational in nature. In order to examine the relationships among the job satisfaction, organizational commitment, and turnover intentions of employees from two casinos in Macau, we first used Pearson correlation, followed by regression analysis to examine whether or not job satisfaction and organizational commitment were valid predictors of turnover intention. The prediction model treated job satisfaction and organizational commitment as independent variables, and turnover intention as the dependent variable. Finally, in order to examine the effects of employees' age and years of experience on job satisfaction, organizational commitment, and turnover intention, a series of two-way Analysis of Variance (ANOVA) were computed.

\section{Results}

\subsection{Correlations}

Table 1 presents means, standard deviations, and zero-order correlations among job satisfaction, organizational commitment, and turnover intention. The Spearman's rho coefficients reveal a significant and positive association between job satisfaction and organizational commitment $(r=.667, p<.01)$, while the association between job satisfaction and turnover intention was positive but not significant $(r=.069, p=.485)$. Finally, the association between organizational commitment and turnover intention was negative but not significant $(r=-.107, p=.275)$. We therefore accept H1a, as this correlation was strong, and partially accept H2a, in which the correlation was negative but weak, but not significant. However, we reject H3a because contrary to expectations, the correlation between job satisfaction and turnover intention was positive.

Table 1. Means, standard deviations, and intercorrelations among three measures

\begin{tabular}{llllll}
\hline \multicolumn{1}{c}{ Measure } & $M$ & $S D$ & 1 & 2 & 3 \\
\hline 1. Job satisfaction & 4.21 & .611 & -- & & \\
2. Organizational commitment & 4.08 & .737 & $.667 * *$ & - & - \\
3. Turnover intention & 4.21 & .753 & .069 & -.107 & - \\
\hline$* * p<.01$. & & & &
\end{tabular}

\subsection{Predictive Relationships}

Standard multiple regression was used to assess the relations between turnover intention as a criterion variable and organizational commitment and job satisfaction as predictor variables. The model indicates that $F(2,102)=4.71, p$ $=.011, R^{2}=.08$. In addition, as shown in Table 2 , organizational commitment $(\beta=.312)$ and job satisfaction $(\beta=-.406)$ were both valid predictors. For our sample, the more satisfied with her job a person is, the more likely she was to leave it; but the more committed to the organization she was, the lower her likelihood of leaving. These findings lead us to accept $\mathrm{H} 2 \mathrm{~b}$ and $\mathrm{H} 3 \mathrm{~b}$. Nevertheless, this model only accounts for $8 \%$ of variance in turnover intention.

Table 2. Regression analysis summary for two variables predicting turnover intention

\begin{tabular}{lccccc}
\hline \multicolumn{1}{c}{ Variable } & $B$ & $S E B$ & $\beta$ & $t$ & $p$ \\
\hline Job satisfaction & .385 & .164 & .312 & 2.35 & .021 \\
Organizational commitment & -.415 & .136 & -.406 & -3.05 & .003 \\
\hline
\end{tabular}

Note. $R^{2}=.08$

\subsection{The Influence of Age and Experience}

The results of our investigation using two-way ANOVA of the possible effects of age and years of experience on job satisfaction, organizational commitment, and turnover intention are presented in Tables 3, Table 4, and Table 5. Age and years of experience were coded as categorical variables, with four age groups being used (i.e., under 25, 26-35, 
36-45, and 46+). These four groups were further subdivided according to years of experience (under 1, 1-5, 6-10, and $11+$ ). Table 3 shows that age did not produce a significant main effect with respect to job satisfaction, $F(3,94)=.221$, $p=.882$. A non-significant main effect was founded for years of experience, $F(3,94)=.053, p=.984$. A non-significant interaction effect between age and years of experience, $F(4,94)=1.591, p=.183$, was also observed.

Table 4 presents the relationships of the respondents' ages and years of experience to their levels of organizational commitment. Again, neither age $(F(3,94)=.518, p=.671)$ nor years of experience $(F(3,94)=.057, p=.982)$ had significant main effects, nor did they produce a significant interaction effect with organizational commitment $(F(4,94)$ $=.706, p=.590)$.

With regard to the effects of age and years of experience on turnover intention, Table 5 shows that the two independent variables produced non-significant main effects (age: $F(3,94)=2.405, p=.072$; years of experience: $F(3,94)=.312$, $p=.817)$, and that their interaction was also not significant, $F(4,94)=.723, p=.579$. Based on these observations, we must reject $\mathrm{H} 1 \mathrm{~b}, \mathrm{H} 2 \mathrm{c}$, and $\mathrm{H} 3 \mathrm{c}$.

Table 3. Summary table for two-way analysis of variance of the effects of age and experience on job satisfaction

\begin{tabular}{lcccccc}
\hline \multicolumn{1}{c}{ Source } & $d f$ & $S S$ & $M S$ & $F$ & $p$ & $\eta^{2}$ \\
\hline Age & 3 & .242 & .081 & .221 & .882 & .007 \\
Experience & 3 & .058 & .019 & .053 & .984 & .002 \\
Age x Experience & 4 & 2.326 & .582 & 1.591 & .183 & .063 \\
Within cells & 94 & 34.353 & .365 & & & \\
Total & 105 & 1899.412 & & & & \\
\hline
\end{tabular}

Table 4. Summary table for two-way analysis of variance of the effects of age and experience on organizational commitment

\begin{tabular}{lcccccc}
\hline \multicolumn{1}{c}{ Source } & $d f$ & $S S$ & $M S$ & $F$ & $p$ & $\eta^{2}$ \\
\hline Age & 3 & .840 & .280 & .518 & .671 & .016 \\
Experience & 3 & .093 & .031 & .057 & .982 & .002 \\
Age x Experience & 4 & 1.527 & .382 & .706 & .590 & .029 \\
Within cells & 94 & 50.843 & .541 & & & \\
Total & 105 & 1806.716 & & & & \\
\hline
\end{tabular}

Table 5. Summary table for two-way analysis of variance of the effects of age and experience on turnover intention

\begin{tabular}{lcccccc}
\hline \multicolumn{1}{c}{ Source } & $d f$ & $S S$ & $M S$ & $F$ & $p$ & $\eta^{2}$ \\
\hline Age & 3 & 3.598 & 1.199 & 2.405 & .072 & .071 \\
Experience & 3 & .466 & .155 & .312 & .817 & .010 \\
Age x Experience & 4 & 1.441 & .360 & .723 & .579 & .030 \\
Within cells & 94 & 46.870 & .499 & & & \\
Total & 105 & 1923.813 & & & & \\
\hline
\end{tabular}

\section{Discussion}

For our sample, job satisfaction had a significant and positive relationship with organizational commitment, and this correlation was strong $(r=.701)$. This finding is in line with previous studies' suggestions that the more satisfied employees are with their jobs, the greater their commitment to their organization will be (Baranik, Rolling, \& Eby, 2010; Lim, 2010). However, the results did not fully support our hypothesis that organizational commitment will have a significant and negative relationship on turnover intention: we did find a negative association $(r=-.187)$, but it was not significant. It should be noted in this context that the majority of our participants $(48.6 \%)$ had between one and five years of experience, and thus might not have developed a strong organizational commitment.

We also found that the more satisfied our respondents said they were with their current jobs, the more likely they were to report planning to leave. This unexpected finding contradicts the previous literature. One possible explanation is that, as Carsteon and Spector (1987) suggested, the availability of job opportunities is an important reason for turnover. Because Macau has abundance of job openings in the gambling industry, it is relatively easy to find an equivalent or even a higher-paid job at a different casino. Even people who are satisfied with their current positions, if they have a chance to receive a higher salary elsewhere, are reasonably likely to leave their organizations.

It should also be taken into consideration that the gambling industry is perhaps uniquely profit-driven, so job satisfaction may not have a direct impact on turnover intention. In addition, the industry in Macau operates on a three-shift system, which may lead employees with high levels of job satisfaction and organizational commitment to nevertheless leave their organizations because their shift schedules are detrimental to their physical wellness and/or interfere with family responsibilities.

When we examined the extent to which job satisfaction and organizational commitment can impact employees' turnover intention, the regression model indicated that both variables were effective predictors. The higher the organizational commitment, the lower the turnover intention $(\beta=-.406)$; however, the greater the job satisfaction, the 
higher the turnover intention $(\beta=.312$ ). As previously discussed, unique features of the gambling industry render the relationship between job satisfaction and turnover intention complicated and far from crystal clear. Additionally, the current study's regression model accounts for a mere $8 \%$ of total variance in turnover intention. This result suggests that other factors may be more important in driving turnover intention, and carries useful implications for other researchers investigating the gambling industry.

With regard to the interaction of age and years of experience with job satisfaction, organizational commitment, and turnover intention, our ANOVA analyses found neither main nor interaction effects. In other words, it was not possible to identify significant differences between age groups or between groups based on years of experience.

\section{Limitations and Possible Future Directions}

When interpreting the results of this study, it should be remembered that only two casinos were involved. For the results to be generalizable, a larger sample size including employees from a larger number of casinos would need to be studied. For example, future researchers might conduct cross-cultural studies, examining employees' attitudes toward the casino industry in Macau, Singapore, and the United States. Another possible issue is that participants may have been in a state of fatigue when responding the survey: even though the instrument contained only 38 simple statements, the unique pressures of their working environment may have meant that they did not have an appropriate amount of time in which to respond to it. Future researchers should consider better methods of distributing surveys to this unusual group. Finally, the current study was a correlational study, which might affect its empirical validity. Including more variables and using covariate techniques to control confounding variables are promising avenues for future study.

\section{Conclusion}

In our study, we found that employees in Macau gambling industry their job satisfaction had a significant and positive relationship with organizational commitment. Organizational commitment had a negative but not significant correlation with turnover intention. Finally, the correlation between job satisfaction and turnover intention was positive but not significant. Based on the regression model, we also found that employees' organizational commitment and job satisfaction can predict their turnover intention. In addition, people's age and experience did not have an influence on their job satisfaction, on their levels of organizational commitment, and on their turnover intention.

The unique contribution of the current study was that, when we examined employees' attitudes toward two casinos in Macau, a positive relationship was found between job satisfaction and organizational commitment, and a positive relationship was found between job satisfaction and turnover intention. It would be expected, both based on the prior literature and intuitively, that a negative relationship between job satisfaction and turnover intention would be found, but we obtained the opposite result. This may have resulted from three causes: that the unemployment rate in Macau is very low, at $1.8 \%$ (Statistics and Census Service, 2015); that salary may be an unusually or disproportionately major consideration for Macau casino employees; and that job opportunities in the gambling industry are abundant and easy to move between.

A number of our participants mentioned that opportunities for promotion in the casinos were rare, and usually based on certain number of years of experience, leading many employees to job-hop in search of higher salaries. It seems that, at least in this particular context, organizational commitment is not a high priority in career development. As far as education is concerned, the majority of employees have only high school diplomas, and consider that this disadvantages them in any job market other than the gambling industry.

Taken as a whole, our research carries several implications for the gambling industry in Macau. First, in order to understand employees' perceptions of their working environment, it is recommended that employee opinion surveys be distributed routinely, and the data thus gathered used as a basis for future corporate policymaking. Second, organizations should provide a sound welfare system and set up bonus schemes to lessen turnover rates. Finally, education and training programs are needed, especially for less experienced workers, to assist them to develop career plans. For example, a casino could work with local universities to provide its employees with a chance of obtaining higher-education diplomas, thereby improving the quality of its own human resources as well as the employees' overall career prospects.

\section{References}

Anderson, C. A., Gentile, D. A., \& Buckley, K. E. (2007). Violent video game effects on children and adolescents: Theory, research and public policy. http://dx.doi.org/10.1093/acprof:oso/9780195309836.001.0001

Baranik, L. E., Rolling, E. A., \& Eby, L. T. (2010). Why does mentoring work? The role of perceived organizational support. Journal of Vocational Behavior, 76(3), 366-373. http://dx.doi.org/10.1016/j.jvb.2009.07.004

Biswas, S. (2009). Job satisfaction and job involvement as mediators of the relationship between psychological climate 
and turnover intention. South Asian Journal of Management, 16, 27-43.

Carsten, J. M., \& Spector, P. E. (1987). Unemployment, job satisfaction, and employee turnover: A meta-analytic test of the Muchinsky model. Journal of Applied Psychology, 72, 374-381. http://dx.doi.org/10.1037/0021-9010.72.3.374

Chang, Y. P. (2010). Short-term employment in work attitude and job performance study: A case study of Miaoli county elementary and junior high school. Unpublished Master's Thesis, http://handle.ncl.edu.tw/11296/ndltd/05570496529780760993

Chi, S. S., \& Zheng, G. (2009). Drivers of job satisfaction as related to work performance on Macao casino hotels: An investigation based on employee survey. International Journal of Contemporary Hospitality Management, 21(5), 561-578. http://dx.doi.org/10.1108/09596110910967809

Chiang, H. C. (2005). A study of leadership behaviors of manager and job characteristics on job satisfaction and organizational commitment of employee: A case study of banks in Tainan. Unpublished Master's Thesis, http://handle.ncl.edu.tw/11296/ndltd/54027885646580021230

Chung, W. L. (2005). The relationship among job satisfaction, organizational commitment, job search, and turnover intention of flight attendant: A case study of an airline in Taiwan. Unpublished Master's Thesis, http://handle.ncl.edu.tw/11296/ndltd/73483761478696068955

Cohen, A. (2003). Multiple commitments in the workplace: An integrative approach. Hillside, NJ: Erlbaum.

Currivan, D. B. (2000). The causal order of job satisfaction and organizational commitment in models of employee turnover. Human Resource Management Review, 9(4), 495-524. http://dx.doi.org/10.1016/S1053-4822(99)00031-5

Ferguson, G. H., \& Ferguson, W. F. (1986). Distinguishing voluntary from involuntary nurse turnover. Nursing Management, 17(12), 43-44. http://dx.doi.org/10.1097/00006247-198612000-00018

Hoppock, R. (1935). Job satisfaction. New York, NY: Harper.

Hou, W. J. (2008). The effect of pay satisfaction and pay equity on the engineer work attitude. Unpublished Master's Thesis, available at http://handle.ncl.edu.tw/11296/ndltd/66293396805608438061

Huang, H. H. (2007). The relationships between job satisfaction and turnover intention of care workers in welfare institutions for the disabled. Unpublished Master's Thesis, http://handle.ncl.edu.tw/11296/ndltd/20006122593489799898

Huang, T. C., \& Hsiao, W. J. (2007). The causal relationship between job satisfaction and organization commitment. Social Behavior and Personality, 35(9), 1265-1276. http://dx.doi.org/10.2224/sbp.2007.35.9.1265

Iverson, R. D., \& Deery, M. (1997). Turnover culture in the hospitality industry. Human Resource Management Journal, 7(4), 71-82. http://dx.doi.org/10.1111/j.1748-8583.1997.tb00290.x

Kah, L. L. (2011). The organizational commitment: The study of mentoring and leader-member exchange (LMX) among auditors in Malaysia-moderating effects of gender. International Journal of Interdisciplinary Social Sciences, 6, 123-146.

Karatepe, O. M., Yavas, U., \& Babakus, E. (2007). The effects of customer orientation and job resources on frontline employees' job outcomes services. Marketing Quarterly, 29, 61-79. http://dx.doi.org/10.1300/J396v29n01_04

Lambert, E. G., Hogan, N. L., \& Keena, L. D. (2015). The impact of job attitudes on private correctional staff's continuance and affective organizational commitment. Journal of Applied Security Research,10, 1-22. http://dx.doi.org/10.1080/19361610.2015.972260

Lance, C. E. (1991). Evaluation of a structural model relating job satisfaction, organizational commitment, and precursors to voluntary turnover. Multivariate Behavioral Research, 26, 137-162. http://dx.doi.org/10.1207/s15327906mbr2601_7

Lim, T. (2010). Relationships among organizational commitment, job satisfaction, and learning organization culture in one Korean private organization. Asia Pacific Education Review, 11(3), 311-320. http://dx.doi.org/10.1007/s12564-010-9087-z

Lo, C. W. (2009). The impact of airlines organizational culture and commitment on service quality. Unpublished Master's Thesis, http://handle.ncl.edu.tw/11296/ndltd/50795780906299490546

Locke, E. A. (1969). What is job satisfaction? Organizational Behavior and Human Performance, 4, $309-336$. http://dx.doi.org/10.1016/0030-5073(69)90013-0

Meyer, J. P., \& Allen, N. J. (1991). A three-component conceptualization of organizational commitment. Human 
Resource Management Review, 1, 61-89. http://dx.doi.org/10.1016/1053-4822(91)90011-Z

Mobley, W. H., Horner, S. O., \& Hollingsworth, A. T. (1978). An evaluation of precursors of hospital employee turnover. Journal of Applied Psychology, 63(4), 408-414. http://dx.doi.org/10.1037/0021-9010.63.4.408

Porter, L. W., Steers, R. M., Mowday, R. T., \& Boulian, N. (1974). Organizational commitment, job satisfaction, and turnover among psychiatric technicians. Journal of Applied Psychology, 59(5), 603-609. http://dx.doi.org/10.1037/h0037335

Salancik, G. R. (1977). Commitment and the control of organizational behavior and belief. In Staw, B. W. \& Salancik, G. R. (Eds.), New Directions in Organizational Behavior (pp. 1-54). Chicago, IL: St. Clair.

Sarah, L. B., \& Daniel, S. J. (2000). Organizational socialization in the host country: The missing link in reducing expatriate turnover. International Journal of Organizational Analysis, 8(4), 380-400. http://dx.doi.org/10.1108/eb028924

Short, T., \& Harris, R. (2010). Challenges in aligning workplace learning with business goals: A perspective from HRD professionals in New Zealand. Australian Journal of Adult Learning, 50(2), 358-386.

Sousa-Poza, A., \& Henneberger, F. (2004). Analyzing job mobility with job turnover intentions: An international comparative study. Journal of Economic, 8, 113-137. http://dx.doi.org/10.1080/00213624.2004.11506667

Statistics and Census Service (2015). Principal indicators. http://www.dsec.gov.mo/default.aspx?lang=en-US

Staw, B. M. (1978). Commitment to a policy decision: A multi-theoretical perspective. Administrative Science Quarterly, 23, 40-64. http://dx.doi.org/10.2307/2392433

Sušanj, Z., \& Jakopec A. (2012). Fairness perceptions and job satisfaction as mediators of the relationship between leadership style and organizational commitment. Psychological Topics, 21(3), 509-526.

Timothy, F. J. (2000). Socialization and organizational outcomes in large public accounting firms. Journal of Managerial Issues, 12, 13-33.

Vroom, V. H. (1964).Work and motivation. New York, NY: John Wiley \& Sons.

Wanous, J. P. (1979). Job survival of new employee. Personnel Psychology, 32(4), 651-662. http://dx.doi.org/10.1111/j.1744-6570.1979.tb02338.x

Wanous, J., \& Lawler, E. E. (1972). Measurement and meaning of job satisfaction. Journal of Applied Psychology, 56, 95-105. http://dx.doi.org/10.1037/h0032664

Williams, L. J., \& Hazer, J. R. (1986). Antecedents and consequences of satisfaction and commitment in turnover models: A reanalysis using latent variable structural equation methods. Journal of Applied psychology, 71(2), 219-231. http://dx.doi.org/10.1037/0021-9010.71.2.219

Yang, J. T. (2008). Effect of newcomer socialization on organizational commitment, job satisfaction, and turnover intention in the hotel industry. Journal of Service Industries, 28(4), 429-443.

http://dx.doi.org/10.1080/02642060801917430

Zhang, S. H. (2004). A study of the personality traits, job satisfaction, and tendencies in turnover of temporary post-secondary school employees. Unpublished Master's Thesis, http://handle.ncl.edu.tw/11296/ndltd/79817623516218551915

This work is licensed under a Creative Commons Attribution 3.0 License. 